\title{
Enhancing Individual with Disability Citizenship through Participation in Sport Activities
}

\author{
Ashraf Kan'an', Malek Jdaitawi ${ }^{2, *}$, Nagla Eltanahi' ${ }^{2}$, Marwa Kholif ${ }^{2}$, Nour Taha², Nahed Nasr ${ }^{2}$, \\ Noha Awad ${ }^{2}$, Nael Anabtawi ${ }^{2}$ \\ ${ }^{1}$ Irbid National University, Jordan \\ ${ }^{2}$ Department of Self-development, Imam Abdulrahman Bin Faisal University, Saudi Arabia
}

Received September 23, 2021; Revised October 27, 2021; Accepted November 29, 2021

\begin{abstract}
Cite This Paper in the following Citation Styles
(a): [1] Ashraf Kan'an, Malek Jdaitawi, Nagla Eltanahi, Marwa Kholif, Nour Taha, Nahed Nasr, Noha Awad, Nael Anabtawi , "Enhancing Individual with Disability Citizenship through Participation in Sport Activities," International Journal of Human Movement and Sports Sciences, Vol. 9, No. 6, pp. 1427 - 1434, 2021. DOI: 10.13189/saj.2021.090639.
\end{abstract}

(b): Ashraf Kan'an, Malek Jdaitawi, Nagla Eltanahi, Marwa Kholif, Nour Taha, Nahed Nasr, Noha Awad, Nael Anabtawi (2021). Enhancing Individual with Disability Citizenship through Participation in Sport Activities. International Journal of Human Movement and Sports Sciences, 9(6), 1427 - 1434. DOI: 10.13189/saj.2021.090639.

Copyright $\odot 2021$ by authors, all rights reserved. Authors agree that this article remains permanently open access under the terms of the Creative Commons Attribution License 4.0 International License

\begin{abstract}
Recently, social and sport activities are important in improving individual health and promoting social integration. Human rights research among disabled individuals is relatively new and along with it, the call for citizenship development in the same demographic is just being initiated. The aim of this study is to investigate the key role of sports activities participation in the promotion of citizenship among disabled individuals. A descriptive study design was implemented using a survey which was adapted to collect data from a sample of 50 participants. A total of 50 participants in a group of special needs with the age of 15-44 years old participated in the study. As for the results, the participants performed moderate levels on the study variables (citizenship and sport participation). The results also illustrated that there were no significant differences on the study variables based on the participants gender and age groups. Added to this, the results showed that there was a significant relationship between sport participation and citizenship dimensions such as active, semi and passive citizenship. The study results extended literature concerning sport activities participation and citizenship behavior and provided evidence to the sport participation role in boosting citizenship. Based on the results, the study recommended to organize several sport activities among individual with special needs in order to help them to engage in the community as well as to improve their citizenship levels. Finally, practical implications are outlines.
\end{abstract}

Keywords Disability, Society, Participation, Citizenship, Sport

\section{Introduction}

In the society, the success of individual with disabilities is related with policy and the general population behavior [1]. Individuals of various ages and abilities are beginning to realize the importance of specific lifestyle which advocates and maintains social integration, health and wellness [2], and this holds true for individuals with disabilities. Specialists in politics, society, psychology and academia have been facing increasing concern when it comes to the participation of disabled individuals in the societal activities, specifically when it comes to citizenship behavior [3]. Despite the fact that individuals suffering from disabilities hold equal citizenship rights, they lack societal participation $[4,5]$.

On account of the present circumstances and policies concerning disabled individuals, policymakers in many countries have been attempting to increase the opportunities for such individuals' participation in society, and their sense of belonging through social rehabilitation and maintenance of their civil, economic, political rights as well as other rights $[6,7,8,9]$. 
Literature brings forward several solutions to the above problem, one of which is to develop individual disabilities citizenship in social and sport activities participation $[2,10]$. Researchers $[2,10]$ revealed that sport activities engagement and participation is among the optimum ways to affirm family and social surroundings, assist in personal development, enhance self-knowledge, along with interpersonal, national and international understanding.

Added to the above, [2] revealed that taking part in competitive and non-competitive sport activities also promotes people's citizenship notwithstanding their economic status, nationality, gender and ability. In relation to this, literature dedicated to disabled individuals revealed that sports participants obtained higher scores in light of social integration compared to their non-participating counterparts [11]. In a related study, [12] revealed a positive relationship between unified special Olympics soccer program and social competence, problem behavior, and friendship activity among intellectually disabled youth, with marked improvement in attitudes of the non-disabled youth towards their disabled counterparts.

According to [10] study, disabled individuals who take part in sports hold a more positive point of view of their physical health and they are not as susceptible to chronic diseases as those who are not sports participants. In addition, [13] revealed that sports participation is a basic right of the individual but for one with disabilities, it provides more advantages.

Disability conceptualization in the viewpoint of society has had key role in changing disability into what used to be a physical issue into one that is by right [6]. In fact, disability is among the identify markers proposed as largely ignored and included in the citizenship theories analyses, regardless of its significance as a social category, upon which new claims can be formed and argued in favor of its inclusion and belonging [6,7]. The perspective of disabled people has been lacking in current citizenship discussion in majority of countries [14,15,9]. More specifically, [15] evidenced that citizenship concept is rarely mentioned in the realm of disability and when it is, it is always through the influence of individual and social context. Additionally, literature dedicated to citizenship and disability [16] shows that disability scholarship has not reached a consensus as to the definition of citizenship, much less its relationship to disability.

Prior studies such as [17] advocated sports as an effective way for individuals to be master of nature and environment, reflecting the way society has transformed its beliefs and changed the rules. However, in the face of academic literature support on sport's support on citizenship in different ways [18]. Nevertheless, only a few studies have been conducted regarding the role of sports activities participation in the promotion of citizenship among disabled individuals. Consequently, there exists a gap in literature concerning the way to determine how disabled individuals can develop their citizenship skills through their sports activities participation. Hence, in the present study, the author examines how sports activities participation may promote citizenship development among disabled individuals. The research is expected to contribute to literature concerning citizenship concept and into the way sports activities participation can lead the way to advocate disabled individuals to take part in such activities in the society in order to acquire a strong sense of citizenship.

\subsection{Aim of the Study}

In relation to addressing the citizenship concept, recent developments in the field of disability research involves the examination of the rights of disabled individuals, specifically, the role of sports activities participation in the promotion of disabled individual's citizenship. Human rights research among disabled individuals is a new field, calling for citizenship development in relation to sports and social activities. Hence, in the present study, the author mainly aims to examine the significant role of sports activities participation in promoting citizenship development among disabled individuals. The research aims to contribute to extending literature on the subject of participation in sports clubs and its role in the citizenship promotion among disabled individuals.

\section{Literature Review}

\subsection{Disability}

Disability is generally related to limitations in functions and according to [19] disability is synonymous to the inferior or deficient difference rather than a neutral one that may call for adaptation. In addition, WHO defines an impairment as a problem in body function or structure, while an activity limitation is a difficulty faced by the individual in task execution. Scholars who dedicated their works to disability topic revealed its relevance to disability related issues and their resolution, and these encompass independent living and the disability rights movement e.g., $[20,21,22]$.

\subsection{Do Sport Promote Citizenship}

Studies in literature revealed that the term sports have been increasingly related to responsibility towards citizenship development qualities and the corresponding challenges $[28,24,25,26]$. Other authors contended that sport-based programs should center on citizenship enhancement of individuals, with the inclusion of those who are disabled [23]. Through the adoption of the UN Convention of Rights of Persons with Disabilities, 
countries have showed their commitment towards facilitating community participation among disabled individuals [17]. More specifically, sport engagement's contribution to citizenship qualities on participants is a topic garnering considerable interest [28]. Sport deployment as an education tool to improve citizenship qualities was also mentioned in literature by studies including $[29,30,24]$, with sport policy discourse evidencing it [31]. Added to the above, the premise that argues the accrual of practical learning from the participation and experience of youth in sport can bring about social citizenship, which in turn, leads to the promotion of a sense of belonging, is a common one [24]. Literature also claims the presence of a relationship between sport and the generation of good, healthy citizens, particularly in recent studies, highlighting queries into the assumed advantages of physical activity and youth sport in advocating youth re-engagement and promoting their positive development, both personal and societal [24,32]. In a similar study, [24] revealed that sports have been, time and again, described as a valuable tool to improve social capital, promote closer social and integration relationships and connections. Parker et al. [1] claimed that despite the evidence supporting the positive influence of sports in the promotion of positive citizenship and social integration among disabled people, evidence is still limited.

\section{Materials and Methods}

A descriptive study design using survey as the instrument of data collection and copies was distributed to participants at multi-sports clubs and sports centers. Specifically, 50 participants from various sports clubs and centers took part in providing cross-sectional data, with large sample from those disabled to obtain their level of citizenship in light of participating in sports. Participants were considered as disabled through self-report, club and centers report to gauge the disabilities effect on the daily functioning of the participants. Prior to data collection, verbal permission was obtained from the participants which voluntary participated. They were informed of the scientific and confidential usage of their participation. The sample constituted 50 participants. The number of male participants was $34(68 \%)$, while the number of female participants was $16(32 \%)$. The participants' ages ranged from 15-44 years. (27) 54\% of the participants were < 33 year; (16) $32 \%$ were $26-32$ years, and (7) $14 \%$ of the participants indicated that their age less than 25 years.

\subsection{Measurement}

Sports activities participation survey was adopted from prior studies by [23] and [34]. The items in the survey included organized and non-organized sport activities (e.g., have you participated in any sports activity? In particular, organized sports activities were included. The participants provide up to six organized sports names that they had participated in over the past months and the number of times weekly with the total participation time in hours and minutes in each sport. The responses were participated in several individual and team sports activities with different time duration (hours/week). The study adopted the citizenship construct measurement from prior studies by $[35,36,37]$. There are 34 items in the questionnaire evaluated along a four-point scale that ranged from 1 (strongly disagree) to 4 (strongly agree), with 2 being disagree and 3 being agree. In addition, there are three forms, namely, passive citizenship (national identity and patriotism), semi-active (civic virtues and loyalty), and active citizenship (social, personal and changed-oriented activity) comprising of various citizenship forms including national identity, loyalty, and social activities involvement, with their own number of measurement items. Items relating to active citizenship are exemplified by the following statements: I engage in sport activities, join sports parties; I become a candidate for political office, participating in sports clubs helps me engage in political activities; I work with community care agencies, support the elderly, engaged in activities that seek to change political and social directions (civic virtues) and (conflict). Items measuring semi-active citizenship are exemplified by; I follow the rules and regulations, become a self-directed learner; I become a creative problem-solver, I adopt entrepreneurial values, engage in self-regulated earning activities, neo-liberal or economic citizenship, and lastly, passive citizenship items include, knowledge and values of the nation's history, support the nation's symbols, have corporate sense of belonging to the nation (national identity), have a sense of pride in the nation, support the claims of the state for the importance of the nation (patriotism), and citizens considered as obedient citizens who are hard-working and who put the needs of the state prior to their personal needs. Some other items included are as follows; Do you maintain a respectful attitude when your country's national anthem is played? Is your country's flag an important symbol for you? Should the rule of law be respected? Do you take good care of your health and physical development? Do you develop your talents and interests? Prior studies [35,36] evidenced the questionnaire's reliability and validity.

Questionnaire reliability and construct validity were established through several analyses, such as translation and through the assistance of 4 experts comprising of behavioral researchers and sport management scholars, who reviewed the instrument and provided their suggestions, which were used to tweak the instrument. Also, the study carried out the instrument's internal consistency using Cronbach's alpha value, which was found to be 0.90 for citizenship and 0.76 for participation in sport activities, indicating good reliability level. 


\subsection{Statistical Analysis}

For statistical analysis, the analysis data of the study was calculated using several tests such as descriptive statistics (Mean and Standard Deviation), t-test, MANOVA and Pearson correlation test with the statistical package for social sciences (SPSS). Mean and standard deviations were used to identify the level of the study variables citizenship subscales and sport participation. These variables are analyzed by the t-test to examine the difference effects of gender levels on citizenship subscales and sport participation. The significant level of 0.05 is set to examine the effects of ages levels on the study variables citizenship subscales and sport participation. We also decided to use the Pearson correlation test in order to determine the relationship between the study variables among the study participants.

\section{Result of the Study}

Descriptive statistics analysis was performed with the Mean and Standard Deviation scores to identify the level of sport participation and citizenship. However, the participants indicated that they have moderate level of participation in the sport activities. Furthermore, descriptive statistics and standard deviations analysis were performed to identify the level of citizenship sub-scales, with the highest mean score active citizenship subscale being $(\mathrm{M}=2.52, \mathrm{SD}=0.42)$, semi-citizenship sub-scale being $(\mathrm{M}=2.45, \mathrm{SD}=0.42)$, and the lowest mean score is passive citizenship subscale being $(\mathrm{M}=2.30, \mathrm{SD}=0.34)$.

Another obtained result pertained to the difference between gender and age level when it comes to sports activities participation and citizenship. This was determined using t-tests among two gender groups and two age groups as displayed in table 1 and table 2 . With regards to citizenship subscales levels, the results showed insignificant difference between gender groups, active citizenship, with male participants scoring higher mean values compared to their female counterparts; semi-citizenship, with male participants scoring higher mean values compared to their female counterparts; passive citizenship, with male participants scoring higher mean values compared to their female counterparts. Insignificant difference was also found in light of age groups, active citizenship, with the participants age less than 25 years scoring lower mean values compared to their counterparts; semi-citizenship, with the participants age less than 25 years scoring lower mean values compared to their counterparts; passive citizenship, with the participants age less than 25 years scoring lower mean values compared to their counterparts.

Table 1. Results of t-test for Gender on Citizenship Scales

\begin{tabular}{|c|c|c|c|c|c|}
\hline Variable & Gender & Mean & SD & $t$-value & Sig. \\
\hline \multirow{2}{*}{$\begin{array}{c}\text { Active } \\
\text { Citizenship }\end{array}$} & Male & 2.63 & 0.40 & \multirow{2}{*}{1.276} & \multirow{2}{*}{0.208} \\
\hline & Female & 2.46 & 0.42 & & \\
\hline \multirow{2}{*}{$\begin{array}{c}\text { Semi } \\
\text { Citizenship }\end{array}$} & Male & 2.48 & 0.34 & \multirow{2}{*}{0.369} & \multirow{2}{*}{0.714} \\
\hline & Female & 2.43 & 0.46 & & \\
\hline \multirow{2}{*}{$\begin{array}{c}\text { Passive } \\
\text { Citizenship }\end{array}$} & Male & 2.36 & 0.34 & \multirow{2}{*}{0.918} & \multirow{2}{*}{0.363} \\
\hline & Female & 2.26 & 0.33 & & \\
\hline
\end{tabular}

Table 2. Results of MANOVA for Age on Citizenship Sclaes

\begin{tabular}{|c|c|c|c|c|c|}
\hline Variable & Age & Mean & SD & F-value & sig \\
\hline \multirow{3}{*}{$\begin{array}{c}\text { Active } \\
\text { Citizenship }\end{array}$} & $\begin{array}{c}<25 \\
\text { years }\end{array}$ & 2.37 & 0.45 & \multirow{3}{*}{1.69} & \multirow{3}{*}{0.191} \\
\hline & $\begin{array}{l}26-32 \\
\text { years }\end{array}$ & 2.54 & 0.33 & & \\
\hline & $>33$ & 2.79 & 0.26 & & \\
\hline \multirow{3}{*}{$\begin{array}{c}\text { Semi } \\
\text { Citizenship }\end{array}$} & $\begin{array}{l}<25 \\
\text { years }\end{array}$ & 2.35 & 0.42 & \multirow{3}{*}{0.156} & \multirow{3}{*}{0.220} \\
\hline & $\begin{array}{l}26-32 \\
\text { years }\end{array}$ & 2.54 & 0.40 & & \\
\hline & $>33$ & 2.56 & 0.41 & & \\
\hline \multirow{3}{*}{$\begin{array}{c}\text { Passive } \\
\text { Citizenship }\end{array}$} & $\begin{array}{c}<25 \\
\text { years }\end{array}$ & 2.23 & 0.35 & \multirow{3}{*}{1.73} & \multirow{3}{*}{0.188} \\
\hline & $\begin{array}{l}26-32 \\
\text { years }\end{array}$ & 2.29 & 0.28 & & \\
\hline & $>33$ & 2.45 & 0.34 & & \\
\hline
\end{tabular}

Added to the above analyses, the study also carried out bivariate correlation analysis to examine the relationship between sports participation and citizenship as presented in table 3. Interestingly, the result revealed that a positive significant correlation was found between the two variables sports activities participation and citizenship among the study participants, which could imply that participation in sport activities of individual with disabilities contributes to citizenship behaviors.

Table 3. Correlation Analysis between Citizenship Scales and Sport Participation

\begin{tabular}{|c|c|c|c|c|}
\hline Variable & Sport Participation & Active Citizenship & Semi Citizenship & Passive Citizenship \\
\hline Sport Participation & ------ & $\begin{array}{c}.424 * * \\
.001 \\
\end{array}$ & $\begin{array}{c}.600 * * \\
.000 \\
\end{array}$ & $\begin{array}{l}.314^{*} \\
.015 \\
\end{array}$ \\
\hline Active Citizenship & $\begin{array}{c}.424 * * \\
.001 \\
\end{array}$ & - & $\begin{array}{l}.297 * \\
.021 \\
\end{array}$ & $\begin{array}{c}.593 * * \\
.000\end{array}$ \\
\hline Semi Citizenship & $\begin{array}{c}.600 z^{* *} \\
.000 \\
\end{array}$ & $\begin{array}{l}.297 * \\
.021 \\
\end{array}$ & -.--- & $\begin{array}{c}.380 * * \\
.003 \\
\end{array}$ \\
\hline Passive Citizenship & $\begin{array}{l}.314^{*} \\
.015 \\
\end{array}$ & $\begin{array}{c}.593 * * \\
.000 \\
\end{array}$ & $\begin{array}{c}.380 * * \\
.003 \\
\end{array}$ & ---- \\
\hline
\end{tabular}




\section{Discussion and Conclusions}

Sports activities have been often evidenced to have a positive relationship with social and health behavioral outcomes but unfortunately, little is known regarding sports participation contribution to citizenship outcomes $[23,17]$. The present study is among the pioneering studies that examined the relationship between sports participation and citizenship behavior among disabled individuals, and the first to determine the association in Jordan. Based on the results of the study, individuals with disabilities have moderate participation levels in sports and citizenship behavior, and despite this result, there are people who continue to practice such activities within their societies. Moreover, the study results showed that sports activities participation is related with enhanced citizenship behavior among disabled individuals. This may be attributed to the fact that disabled individuals are less involved in social activities and thus, their participation in sports teams and activities assist their social engagement in the community, with other factors influencing such participation.

Additionally, sports activities participation may lead to enhanced focus and control of actions among participations through observation, and this may also lead to decent and timely actions feedback. Literature findings showed that sports activities enable increased attention and decreased hyperactivity among disabled individuals $[38,39]$. The result may also be related to the fact that individuals suffering from disabilities may have felt their right to participate in different sports activities, as [40] stated, disabled people need access to different supports and assistance. Also, the positive correlation between variables may be related to the right of the participants to take part in sports and enhance their citizenship behavior as the government of Jordan provides support for them to make sure that sports clubs and centers are facilitated for their usage. This may also be related to the implementation of various resources within sports clubs and centers, with state-of-the-art facilities that encourage individual's participation and citizenship behavior.

In Jordan, sports clubs and centers are fully aware of their role in developing citizenship qualities and as such, are committed to their role in assisting those that are disabled $[24,25]$. In other words, sports clubs and centers are not focused on developing citizenship quality more than ever, and hence, a positive relationship was found between citizenship behavior and sports activities participation among the study participants. The result of the study is aligned those conducted by [28], which found engagement in sport-based programs to be an agent for social and personal transformation. It is somewhat consistent with prior studies like [24], who revealed that disability behaviors are related to citizenship. Moreover, [24] showed that youth's participation in sports activities can lead to their social citizenship development and their sense of belonging. Hence, it is pertinent to establish polices to enhance disabled individuals' participation in the social activities including sports activities to enhance their citizenship behavior and their whole life. Moving on to the significant differences in gender when it comes to sports participation and citizenship behavior relationship, this study found no differences on participating and citizenship between male and females. This may be attributed to the valued and prioritized equivalent sports for the genders, with freedom and opportunity to practice any sports activity. Male and female participants indicated that they had equal opportunities to contribute to societal needs. Literature generally lacks studies on the relationship between individual characteristics and citizenship behavior. No theoretical or empirical finding has been reported regarding gender differences when it comes to knowledge and reflection elements of citizenship competencies [41]. However, [42] evidenced that sports participation is a male dominated field and participation in sports usually lessens with increasing age.

In a related study, female participants scored higher compared to male participants when it comes to citizenship domains, with the former group displaying more adaptive behaviors, social skills and good social relations orientation compared to the latter [43]. The obtained result may also be related to the fact that disabled individuals are largely dependent on family or others, for support. Both genders are provided opportunities to participate in sports activities with sports clubs creating and facilitating a welcoming and inclusive environment for both genders. Moving on to differences based on age groups, although, insignificant differences were observed, elderly participants reported higher levels of citizenship behavior compared to younger ones, in what appears to be an expected result as Jordan mature disabled individuals generally take part in community activities and they have sports experiences along with experiences in national, social and political practices and activities. Also, parents generally fear for their children to be teased or injured [44]. Nevertheless, frequency of age and gender groups are not ideal characteristics to use when comparing health statuses throughout groups as maintained by $[45,46,47,48]$. Other studies revealed that individuals of varying disability statuses may display low physical activity intensity owing to their physical impairment although they have an equitable view of communal involvement [49].

\subsection{Conclusions}

The primary aim of this study is to provide deeper insight into the citizenship concept. The study first provided a description of citizenship as a formal status after which the concept is related with disability. The study then examined the citizenship practice in relation to disabled individuals and their sports activities participation. To the best of the author's knowledge, this 
is a pioneering study that provided a description of the relationship between sports participation and citizenship behavior among disabled individuals. Literature on individuals with disabilities and their participation in sports and citizenship behavior has been limited. The present study identified the differences between the factors in order to provide examples to inspire local government to focus on the access of disabled individuals to sports activities. The government of Jordan facilitates the provision of services and meeting of rights to disabled individuals through social and sports activities initiatives promotion. In fact, there are many sports organizations that cater to disabled individuals, and are government-funded, using various approaches to promote sports activities among such disenfranchised group, to enhance their citizenship behaviors. The results of the present study are expected to contribute to extant literature on citizenship behaviors and the way sports participation is related to it, encouraging positive individual lifestyles and supporting a sense of belonging. The findings inspire policy makers to collaborate and share information and knowledge as to how individuals' sports participation and exercises can be promoted and enhanced to improve life qualities among people [50,51].

\subsection{Strengths and Limitations}

In the face of its contributions, this study is not without limitations - these limitations need addressing in future and further studies. The first limitation concerns the focus on national government clubs and centers that promote sports activities for disabled people, without including private clubs and centers. There are many private centers that also promote sports among disabled people, and as such, generalization of findings has to be done with caution. The second limitation is related to only a portion of the disabled individuals and thus, the findings should not be generalized to the whole disabled individuals' population. Future studies may include as many disabled individuals as possible from different population groups. The third limitation is the short time period with which the study was conducted owing to the time limitations. In this case, future studies may carry out a long-term study to gain more accurate and reliable findings. Finally, although, quantitative method was widely used in the literature [52,53,54,55], a long-term study adopting other data collection methods (mixed method) is required to gather opinions and perceptions concerning sports activities participation and citizenship behavior.

\section{REFERENCES}

[1] S. Mavandadi, K. Rook, J. Newsom. Positive and negative social exchanges and disability in later life: An investigation of trajectory of change. The Journal of
Gerontology Series B Psychological Sciences and Social Sciences, Vol. 62, No. 6, S361-70, 2007. DOI: 10.1093/geronb/62.6.S3611.

[2] T. Malkinson, C. He. Sports for global citizenship. IEEE Canada International Humanities Technology Conference-IHTC, 2014. DOI: 10.1109/IHTC.2014.71475 47

[3] A. Alevriadou, L. Lang. Active citizenship and contexts of special education. Education for the inclusion of all students. CiCe Central Coordination Unit. Institute for policy studies in education, London Metropolitan University, London, UK, 2011.http://www.cicea.eu/docs/GUIDELINES/general/gui delines-12.pdf

[4] R. Halvorsen, B. Hvinden, J. Bckenbach, D. Ferri. The changing disability policy system: Active citizenship and disability in Europe. Routledge, ISBN: 9781138652880, 2017. https://routledge.com

[5] N. Altermark. Citizenship inclusion and intellectual disability. Routledge, 2017.https://doi.org/10.4324/978131 5109947.

[6] A. Hiddinga, M. Langen. Practicing of belonging: Claiming elderly care through deaf citizenship. Citizenship Studies, 2019. DOI: $10.1080 / 13621025.2019 .1651086$.

[7] E. Isin, B. Turner. Citizenship Studies: An Introduction.” In Handbook of Citizenship Studies, edited by E. F. Isin, and B. S. Turner, 1-10, 2002. London: Sage. DOI: $10.4135 / 9781848608276 . n 1$

[8] K. Rummery. Disabled Citizens and Social Exclusion: The Role of Direct Payments. Policy \& Politics, Vol. 34, No. 4, 633-50, 2006. https://doi.org/10.1332/0305573067785531 32.

[9] H. Meekosha, L. Dowse. Enabling Citizenship: Gender, Disability and Citizenship in Australia." Feminist Review, Vol. 57, No. 1, 49-72, 1997. https://doi.org/10.1080/01417 7897339650 .

[10] F. Eminovic, R. Nikic, I. Stjkovic, S. Pacic. Attitudes towards inclusion of persons with disabilities. Sport Science, Vol. 2, No. 1, 72-77, 2009. Gaete-Reyes M. 2015. "Citizenship and the Embodied Practice of Wheelchair Use." Geoforum 64:351-61. https://doi.org/10.1051/e3sconf/202 127312093

[11] C. Hanson, D. Nahavi, H. Yuen. The effect of sport on level of community integration as reported by Persons with spinal cord injury. American Journal of Occupational Therapy, Vol. 55, 332-338, 2000. DOI: 10.5014/ajot.55.3.332

[12] E. Ozer, L. Douglas. The impact of participatory research on urban teens: A $\mathrm{n}$ experimental evaluation. American Journal of Community Psychology, Vol. 51, No. 1, 2012. DOI: $10.117 / \mathrm{s} 10464-012-9546-2$.

[13] A. Devine, A., Carroll, S. Naivalu, S. Seru. Promoting effective implementation of disabilities inclusive sports for development programmes. Lessons learns from Australian government program in the Pacific. Journal of Paralympic Research Group, 9, 2017. DOI: 10.32229/PARASAPO.9.0 $-43$

[14] M. Sepulchre, R. Lindqvist. Enhancing active citizenship for persons with psychosocial disabilities. Scandinavian 
Journal of Disabilities Research, Vol. 18, No. 4, 316-327, 2017. https://dx.doi.rg/10.1080/15017419.2015.1105288.

[15] J. Morris. Citizenship and disabled people: A scoping paper prepared for the disability rights commission, 2005 http://enil.eu/wp-content/upload/2012/07/citizenship-and-d isabled people. A-scoping-paper.

[16] M. Sepulchre. Disability and citizenship behavior. Interdisciplinary Disabilities Studies, 2020. DOI: 10.4324/9781003030676.

[17] M. Khan, et al. The promotion of democratic behavior and the role of media. Journal of Education and Practice, Vol. 6 , No. 1, 88-96, 2015.https://files.eric.ed.gov/fulltext/EJ1083 871.pdf

[18] H. Grainger. From immigrant to overstayer: Samoan identify, rugby and culture politics of race and nation in Aotearoa. Journal of Sport and Social Issues, Vol. 30, No. 1, 45-61, 2006.

[19] J. Le Clair. Transformed identity: from disabled person to global Paralympian. Sport in Society, Vol. 14, No. 9, 1116-1130, 2011. DOI:10.1080/17430437.2011.614768

[20] N. Altermark. Citizenship inclusion and intellectual disability. Routledge, 2016. http://doi.org/10.4324/978131 5109947.

[21] R. Halvorsen, M. Crocco, R. Jacobsen, A. Segall. Less arguing, more listening: Improving civility in classroom. Philosophy Delta Kappan, Vol. 99, No. 5, 67-71, 2018. DOI: $10.1177 / 0031721718754818$

[22] M. Sepulchre, R. Lindqvist. Enhancing active citizenship for persons with psychosocial disabilities. Scandinavian Journal of Disabilities Research, Vol. 18, No. 4, 316-327, 2018. DOI: $10.1080 / 15017419.2017 .1105288$

[23] A. Parker, H. Morgan, S. Farooq, B. Moreland, A. Pitchford. Sporting intervention and social change: football, marginalized youth and citizenship development. Sport, Education and Society, Vol. 24, No. 3, 298-310, 2019. DOI: 10.1080/13573322.2017.1353493.

[24] D. Garratt, H. Piper. Dangerous liaisons: Youth sport, citizenship and intergenerational mistrust. International Journal of Sport Policy and Politics, Vol. 8, 1-14, 2014. DOI:10.1080/19406940.2014.896390.

[25] T. O’Donovan, A. MacPhail, D. Kirk. Active citizenship through sport education. Education 3-13. International Journal of Primary, Elementary and Early Years Education, Vol. 38, No. 2, 203-215, 2010. https://doi.org/10.1080/030 04270903153947.

[26] A. Parker, R. Meek, G. Lewis. Sport in a youth prison: Male young offenders' experiences of a sporting intervention. Journal of Youth Studies, Vol. 17, No. 3, 381-396, 2014. DOI: $10.1080 / 13676261.2013 .830699$.

[27] B. Green. Sport as an agent for social and personal change. In V. Girginov (Ed.), Management of sports development (pp. 129-145, 2008). Oxford: Butterworth-Heinemann. https://doi.org/10.4324/9780080570099.

[28] M. Collins, T. Kay. Sport and social exclusion (2nd ed.). London: Routledge. Degener T. 2016. Disability in a human rights context. Laws, Vol. 5, No. 3, 35, 2014. DOI: 10.3390/laws5030035.
[29] D. Eley, D. Kirk. Developing citizenship through sport: The impact of a sport-based volunteer programme on young sport leaders. Sport, Education and Society, Vol. 7, No. 2, 151-166, 2002. https://doi.org/10.1080/135733202200001 8841.

[30] D. Garratt. 'Sporting citizenship': The rebirth of religion? Pedagogy, Culture and Society, Vol. 18, No. 2, 123-143, 2010. https://doi.org/10.1080/14681366.2010.488040.

[31] S. Bradbury, T. Kay. Stepping into community? The impact of youth sport volunteering on young people's social capital. In M. Nicholson \& R. Hoye (Eds.), Sport and social capital (pp. 285-315). London: Butterworth-Heinemann, 2008. https://dspace.lboro.ac.uk/2134/24525.

[32] K. Armour, R. Sandford, R. Duncombe. Positive youth development and physical activity/sport intervention mechanisms leading to sustained impact. Physical Education and Sport Pedagogy, Vol. 18, No. 3, 256-281, 2013. https://doi.org/10.1080/17408989.2012.666791.

[33] M. Amanda, A. Timperio, H. Brown, T. Hinkley. Associations between organized sport participation and classroom behavior outcomes among primary school-aged children. PLoS One, Vol. 14, No. 1, 2019. DOI 10.1371/journal.pone.0209354.

[34] S. Vella, D. Cliff, C. Magee, A. Okely. Sports participation and parent-reported health related quality of life in children: Longitudinal association. The Journal of Pediatric, Vol. 164, No. 6, 1469-74, 2014. http"//doi.org/10.1016/j.jpeds.2014. 01.071 .

[35] A. Zalewska, B. Krzywosz-Rynkiewicz, Psycologiczne portery mlodych obywateli. Warszawa: Wydawnictwo SWPS Academia, 2011.DOI:10.4467/20843879PR.15.019 .4462 .

[36] B. Krzywosz-Rynkiewicz, A. Zalewska. Measuring young peoples citizenship activity. Citizenship Teaching \& Learning, Vol. 12, No. 2, 141-150, 2017. DOI: 10.1386/ctl.12.2.141_1.

[37] B. Krzywosz-Rynkiewicz, A. Zalewsk, K. Kennedy. Young people and active citizenship in Post-Soviet time. A challenge for citizenship education. Routledge Taylor \& Francis Group, 2018. https://www.routledge.com/Young-P eople-and-Active-Citizenship-in-Post-Soviet-Times-A-Cha llenge-for/Krzywosz-Rynkiewicz-Zalewska-Kennedy/p/bo ok/9780367272029

[38] A. Watson, A. Timperio, H. Brown, T. Hinldey, K. Hesketh. Associations between organized sport participation and classroom behavior outcomes among primary school-aged children. PLOS One, Vol. 14, No. 1, e0209354, 2019. http://doi.org/10.1371/journal.pone.0209354.

[39] Y. Chang, Y. Tsai, T. Chen, T. Hung. The impacts of coordinative exercise executive function in kindergarten children: An EPR study. PubMed, Experimental Brain Research, Vol. 228, No. 2, 2013. DOI: 10.1007/s00221-012-33609.

[40] A. Waldschmidt, M. Sépulchre. Citizenship: reflections on a relevant but ambivalent concept for persons with disabilities, Disability \& Society, Vol. 34, No. 3, 421-448, 2019, DOI: 10.1080/09687599.2018.1543580.

[41] F. Geijsel, G. Ledoux, R. Reumerman, G. Dam. Citizenship 
in young peoples daily lives: Differences in citizenship competences of adolescents in the Netherland. Journal of Youth Studies, Vol. 15, No. 6, 1-19, 2012. DOI: $10.1080 / 13676261.2012 .671932$.

[42] B. Buraimo, B. Humphreys, R. Simmons. Participation, engagement and intensity of sports participants. Analysis of the taking part survey. University of Central Lancashire, United Kingdom, 2010. https://www.gov.uk

[43] A. Rose, K. Rudolph. A review of sex differences in peer relationship processes: Potential trade-offs for the emotional and behavioral development of girls and boys. Psychol Bull, Vol. 132, No. 1, 98-131, 2006. DOI: 10.1037/0033-2909.132.1.98.

[44] S. Geidne, K. Jerlinde. How sports clubs include children and adolescents with disabilities in their activities. A systematic search of peer-reviewed articles. Sport Science Review, Vol. 1, No. 2, 29-52, 2016. DOI: 10.1515/ssr-2016-0002.

[45] S. Ross, K. Bogart, S. Logan, L. Case, J. Fine, H. Thompson. Physical activity participation of disabled children. A systematic review of conceptual and methodological approaches in Health research, Vol. 4, No. 187, 2016. DOI: 10.3389/fpubh.2016.00187.

[46] W. Marquis, B. Baker. Sports participation of children with or without developmental delay: prediction from child and family factors. Research Development Disability, Vol. 37, 45- 54, 2015. DOI: 10.1016/j.ridd.2014.10.028.

[47] R. Arim, L. Findlay, D. Kohen. Participation in physical activity for children with neurodevelopmental disorders. International Journal of Pediatr, Vol. 2012, 2012. DOI: $10.1155 / 2012 / 460384$.

[48] K. Lauruschkus, L. Westbom, I. Hallström, P. Wagner, E. Nordmark. Physical activity in a total population of children and adolescents with cerebral palsy. Research Development Disability, Vol. 34, No. 1, 157-67, 2013. DOI: 10.1016/j.ridd.2012.07.005.
[49] G. King, T. Petrenchik, D. Dewit, J. McDougall, P. Hurley, M. Law. Out-of-school time activity participation profiles of children with physical disabilities: a cluster analysis. Child Care Health Development, Vol. 36, No. 5, 726-41, 2010. DOI: $10.1111 /$ j.1365-2214.2010.01089.x.

[50] Nur Cholis Majid, Fauzi , "The Effect of Sprint Training on Vertical Jump Height of Female Youth Volleyball Players," International Journal of Human Movement and Sports Sciences, Vol. 9, No. 2, pp. 334 - 339, 2021. DOI: 10.13189/saj.2021.090222.

[51] A. Rasheed, R. Abduljawad, S. Mabrouk, M. Jdaitawi, M. Abdulmonem. Physical fitness training program using electronic simulation games to foster psychological health among university students during COVID-19 pandemic. International Journal of Human Movement and Sports Sciences, Vol. 9, No. 3, pp. 421-427, 2021. DOI:10.13189/saj.2021.090305.

[52] M. Jdaitawi. Does flipped learning promote positive emotions in science education? A comparison between traditional and flipped classroom approaches. Electronic Journal of e-learning, Vol. 18, No. 16, 516-524, 2020. DOI: 10.34190/JEL.18.6.004

[53] M. Jdaitawi. The effect of flipped classroom strategy on students learning outcomes. International Journal of Instruction, Vol. 12, No. 3, 665-680, 2019. http://doi.org/10.29333/iji.2019.12340a

[54] M. Jdaitawi. The effect of using problem-based learning upon students emotions towards learning and levels of communication skills in three different disciplines. Croatian Journal of Education, Vol. 22, No. 1, 207-240, 2020. http://doi.org/10.15516/cje.v22i13215

[55] M. Jdaitawi, A. Rasheed, M. Gohari, Y. Raddy, M. Ayden, A. Abas, A. Hasan, A. Khatiry. The determinants of leisure attitudes: Mediating effect of self-efficacy among students from science, engineering and medicine colleges. Journal of Turkish Science Education, Vol. 17, No. 2, 242-252, 2020. DOI: $10.36681 /$ tused.2020.24 